\title{
A New Science for a Post-Frontier World
}

\author{
Donald Worster ${ }^{1}$
}

\begin{abstract}
The driving force behind the North American frontier were waves of economic migrants from Europe and their offspring, competing against the indigenous people and eventually replacing them. But those waves were backed up by the power of the American and Canadian nation states, with their well-armed military, their well funded railroads, and other technology and capital. Science too was initially on the side of the invaders. But after World War One that frontier began to run out of free, abundant land. Then began what I will call a "post-frontier" science, especially ecological in content, that represented a very different attitude toward the white man's conquest. Scientists like Frederick Clements, John C. Weaver, Paul Sears, and Stan Rowe, all natives to the Great Plains, laid the foundations for what is now a powerful critique of frontier agriculture. This article aims to summarize that critique briefly but focus mainly on the more recent work of Wes Jackson, founder and longtime president of the Land Institute. He has strongly criticized the frontier ethos for its the lack of understanding of the native ecology of the grasslands. In its place he has offered a vision of "perennial polyculture," using nature as a model for agriculture in an era of limits. That model has not only been making a growing impact on American thinking but has now spread to other continents. Will the end of this frontier cycle and scientific reappraisal turn out to be what Jackson calls a "new agriculture," one based on learning from the past and one that can change farming all over the world?
\end{abstract}

Keywords: Environmental History; Frontier Agriculture; Wes Jackson; Land Institute.

\footnotetext{
${ }^{1}$ Ph.D. in History, Yale University. Hall Distinguished Professor of American History at the University of Kansas. Distinguished Foreign Expert and senior professor in the School of History of Renmin University of China. dworster@ku.edu
} 
I $\mathrm{n}$ American and Brazilian mythology there is always another frontier to be discovered and made civilized ${ }^{2}$. But agriculturally, we can say with certainty that the last large frontier of unsettled, unplowed land in the United States was the Great Plains, which before the 1870s had long known the presence of people but not the effects of the plow $^{3}$. Over a 50-year period, lasting through the 1920s, this native grassland was violently transformed into a landscape of fences, cattle, and wheat, from Texas northward into Canada. But in the 1930s severe drought and high winds turned the entire region, especially the newly plowed farms, into the infamous Dust Bowl, ranking among the worst episodes of soil erosion in world history. That frontier had come to a rapid end.

During those same years, in the droughty summer of 1936 and a few hundred miles east of the Dust Bowl ${ }^{4}$, future scientist Wes Jackson was born. He was the child of small farmers struggling to survive on the outskirts of the Kansas state capital of Topeka. After university training in botany and plant genetics, at the age of forty, Jackson became the founder of the Land Institute, located outside Salina, Kansas, an organization devoted to applying natural science to the design of agriculture and preventing future dust bowls. Its mission, still going strong today like its founder, has been to revolutionize agriculture through the science of ecology. Jackson is a selfproclaimed revolutionary. At the core of his revolution, he urges farmers to follow nature rather than ignore it. Before the coming of the white man, nature on the Great Plains had evolved an interdependent and resilient set of ecosystems, uniting plants, animals, climates and soils into what we call the prairie, and those natural systems should have been rigorously studied and followed by humans, not ignored and destroyed. Much more of the prairie should have been preserved intact as a source of land wisdom. In other places it had to modified to feed a growing human population, but farmers should have followed nature's model and tried to preserve permanent vegetation that could hold the soil in place. Jackson's remedy for the plains includes

\footnotetext{
${ }^{2}$ Frederick Jackson Turner, The Significance of the Frontier in American History (Madison: State Historical Society of Wisconsin, 1894); Donald Grant Creighton, The Empire of the St. Lawrence: A Study in Commerce and Politics (Toronto: University of Toronto Press, 2002); Sandro Dutra e Silva, No Oeste a Terra e o Céu: A Expansão Da Fronteira Agrícola No Brasil Central (Rio de Janeiro: Mauad X, 2017).

${ }^{3}$ Donald Worster, Dust Bowl: The Southern Plains in the 1930s (New York: Oxford University Press, 1979).

${ }^{4}$ Ibid.
} 
new perennial forms of wheat, corn, soybeans, and sorghum, planted together with nitrogen-building legumes and drought-resistant forbs and grasses. The result should be a natural "polyculture" rather than a traditional "monoculture."

Such a revolution would do more than save the Great Plains. It would promote a new paradigm for agriculture that could be applied all over the earth. It fix a 10,000year-old flaw-the annual plowing of land and the planting of short-term crops. The first farmers in history lacked the scientific know-how to prevent that flaw, and their successors have haplessly continued to risk wind and water erosion and the loss of topsoil, degrading and even dooming many civilizations.

Briefly, I want to offer as an example a new generation of scientists like Jackson, who are leading us toward a post-frontier, science-informed world. They are seeking to revolutionize not only farming but the entire human relationship with nature. We historians have written much about those ancient times when peasant agriculture replaced hunting and gathering, with attendant changes in worldviews. We have tracked the subsequent rise of social inequality, landlordism, and capitalism, replacing in turn those peasant ways. We are quite familiar with the old dialectics at work. Are we now, however, witnessing something quite new--the emergence of worldviews and agricultural practices based on modern science? Will that development transcend all the older dialectics and usher in a post capitalist, post industrial era? Will it be scientists who henceforth control how we think about and use the land?

First a confession: I am a former board member of the Land Institute and a personal friend of Wes Jackson. But this afternoon my aim is to raise carefully and objectively the historical implications of his work. He assumes that the natural sciences can become, and even will become, the main agent for revolutionary change, and that through the sciences we will find our way to a more sustainable, and he would add, a morally better, future.

Jackson comes out a history of scientific assessment of frontier farming. In the case of the Great Plains, scientists first began that assessment during the 1930s, just as the agricultural frontier was self-destructing. Out of Nebraska came one of the first 
great ecologists in the United States, Frederic Clements, author of the pioneering treatise The Development and Structure of Vegetation (1904) $)^{5}$ and Plant Succession $(1916)^{6}$, which emphasized how prairies develop over time until they reach, if they are not disturbed, a climax state of stable adaptation to climate. This theory was offered by Clements in the dirty thirties as a law of nature that farmers had violated. Two of his disciples, John Weaver and Evan Flory, both ecologists at the University of Nebraska, carried on that scientific critique as the first big dust storms passed over the plains. They wrote that a new era of land conservation was needed, based on the scientific study of "Nature's crops and Nature's way of making the most of a sometimes adverse environment" published a landmark book, Deserts on the March, which warned that farmers were turning the Plains into a desolate, drifting Sahara ${ }^{8}$. His cure for the crisis entailed the appointing of a resident ecologist for each country of the plains to supervise land use. Out of that legacy of Great Plains scientists encountering the Dust Bowl came Wes Jackson and the Land Institute.

In his first book New Roots for Agriculture, published in $1980^{9}$, Jackson called not for resident ecologists as farm advisers but for "a bio-technical fix." By the 1990s the Land Institute was ready for concentrated work on that fix, nothing less than their radical redesign, based on mimicking the prairie landscape. The Institute had become a scientific research center, with shiny new greenhouses, acres and acres of experimental plots, and a carefully assembled team of Ph.D. scientists trained in plant breeding, soil ecology, and ecosystem management, with a substantial budget and many highly admired papers published among their fellow scientists. Similar research programs in ecological or natural systems agriculture were appearing in Australia, Sweden, and China, with Africa and South America demanding attention too. This international movement was a major legacy of the Dust Bowl years that so far has

\footnotetext{
${ }^{5}$ Frederic E. Clements, The Development and Structure of Vegetation (Lincon, Nebraska: The Woodruff-Collins Printing Company, 1904).

${ }^{6}$ Frederic E. Clements, Plant Succession; an Analysis of the Development of Vegetation (Washington: Carnegie Institution of Washington, 1916).

${ }^{7}$ Donald Worster, Nature's Economy: A History of Ecological Ideas (New York: Cambridge University Press, 1994); Worster, Dust Bowl: The Southern Plains in the 1930s.

${ }^{8}$ Paul Bigelow Sears, Deserts on the March, 4th ed. (Norman: University of Oklahoma Press, 1980).

${ }^{9}$ Wes Jackson, New Roots for Agriculture (Lincon, Nebraska: University of Nebraska Press, 1985).
} 
received little acknowledgement from farmers or historians. And Jackson himself, the farmers' son, has come to be recognized by a slew of prestigious awards, including a MacArthur grant and the "alternative Nobel" prize, the Right Livelihood Award.

Along the way Jackson had become, at the same time, a trenchant critic of many of his fellow scientists, arguing that modern science had begun as a pure pursuit of "the truth and nature of things" but had become corrupted into "an instrument for power or control" over the natural world. The chief corrupter, he charged, was capitalism and "the industrial mind." Therefore, science, before it could be trusted by society, had to be purged and restored to its original integrity. Some of his critique of science came from Jackson's growing friendship with the Kentucky poet Wendell Berry, a self-proclaimed agrarian and traditionalist who celebrated the quality of knowledge and virtue among small farmers. Berry accepted science, but gingerly and with many qualifications. For example, in his introduction of Jackson's 2011 book Nature as Measure ${ }^{10}$, Berry wrote that science could be trusted only if it became a "counter-science, or a science conscientiously self-limiting." He would accept science only when it had put itself in service to "nature, locality, and local community"-that is, when it had adopted a more humble and deferential role. This "self-limiting" science was what Jackson likewise came to envision.

I have not seen or heard from either Jackson or Berry exactly how that selflimitation among scientists can come about. Mainly it seems to require a moral change among scientists. And so they are both calling for not only a scientific revolution on the farm but also a moral revolution in science, one rooted in the moral philosophy of agrarianism. Berry wants to restore America to the land of the small farmer as the cornerstone of the good society-an ideal that we rightly associate with Thomas Jefferson in the $18^{\text {th }}$ century. And this is this ideal lies in the heart and mind of Wes Jackson as well. Where the two seem to disagree is over the how much value we should give to "traditional knowledge," with Berry preferring to follow older traditions in agriculture, while Jackson is giving far greater weight to modern scientific research. The scientific researchers at the Land Institute seem to work from a shared view that

\footnotetext{
${ }^{10}$ Wes Jackson, Nature as Measure: The Selected Essays of Wes Jackson (Berkeley, Califórnia: Counterpoint Press, 2011).
} 
agriculture has been fatally flawed by limits of knowledge and by a lack of humility toward the natural order. They work with the confidence that modern science knows best, but the goal is not to serve Wall Street, the bankers, and the agribusiness mentality.

This post Dust Bowl legacy on the Great Plains has many parallels in the postwar environmental movement, ranging from Barry Commoner and Paul Ehrlich, Rachel Carson and Aldo Leopold, and we can find anticipations of it with the likes of George Perkins Marsh, John Wesley Powell, and all those prairie ecologists of the 1930s and after (to name only the more prominent North Americans). Scientists have been in the forefront of campaigns against soil erosion, loss of biodiversity, chemical pollution, and now of course global climate change. To the extent that environmental issues have gained traction in recent decades, it has largely been due to the scientific community, marking a shift in power away from older leadership elites. There is to be sure a lot of resistance to that shift, coming mainly from rural, religious fundamentalist, and conservative elements in the United States and other countries. But it seems clear to this historian at least that the natural sciences have never been so necessary or so prominent in policy matters or cultural discourse oas they are today. Wes Jackson exemplifies that shift, away from the farm and countryside to international research circles funded by philanthropy and government.

I submit that this shift in power has occurred because scientists have become more self-assertive, not self limiting. They have come to feel more free to work on what they regard as important, and increasingly that entails a broader role in reforming society: slowing population growth, preventing mass epidemics, protecting fragile ecosystems, searching for new forms of energy, and farming more sustainably. Scientists are not being elected to public office in great numbers, but they are being heeded by the public to a degree unmatched in history. So is this rise in status a portent of the future-a coming shift of huge proportions in leadership and authority? Do scientists offer a new world view that is changing human behavior? Or is a shift going on because of the material problems we face today,-problems that are material as much or more than moral, problems that require "bio-fixes" that no one else but scientists can deliver? 
The Dust Bowl disaster of the Great Plains was the outcome of frontier economic expansion. It had little to do with scientists being corrupted, and everything to do with demography, markets, and capitalist reorganization of labor and land. But the outcome did encourage scientists to offer remedies. And now that has become the norm all over the earth. Who can best address the modern problems of sustainability? It won't be capitalism, we can be fairly sure. I wager that it won't be small farmers either, who are steeped in old ways of thinking. I am absolutely sure it won't be historians. We are here merely to witness and to write the history of changes on the land and in the minds of people.

\section{REFERENCIAS}

Clements, Frederic E. Plant Succession; an Analysis of the Development of Vegetation. Washington: Carnegie Institution of Washington, 1916.

---. The Development and Structure of Vegetation. Lincon, Nebraska: The WoodruffCollins Printing Company, 1904.

Creighton, Donald Grant. The Empire of the St. Lawrence: A Study in Commerce and Politics. Toronto: University of Toronto Press, 2002.

Dutra e Silva, Sandro. No Oeste a Terra e o Céu: A Expansão Da Fronteira Agrícola No Brasil Central. Rio de Janeiro: Mauad X, 2017.

Jackson, Wes. Nature as Measure: The Selected Essays of Wes Jackson. Berkeley, Califórnia: Counterpoint Press, 2011.

---. New Roots for Agriculture. Lincon, Nebraska: University of Nebraska Press, 1985.

Sears, Paul Bigelow. Deserts on the March. 4th ed. Norman: University of Oklahoma Press, 1980.

Turner, Frederick Jackson. The Significance of the Frontier in American History. Madison: State Historical Society of Wisconsin, 1894.

Worster, Donald. Dust Bowl: The Southern Plains in the 1930s. New York: Oxford University Press, 1979.

---. Nature's Economy: A History of Ecological Ideas. New York: Cambridge University Press, 1994. 


\title{
Una Nueva Ciencia para un Mundo Pos-Frontera
}

\begin{abstract}
RESUMEN
La fuerza motora detrás de la expansión de la frontera norteamericana estuvo constituida por sucesivas olas de migrantes europeos y sus descendientes, quienes por razones económicas, competían contra los pueblos indígenas y eventualmente los reemplazaron. Pero aquellas oleadas estuvieron alentadas por la fuerza de los estados nacionales estadounidense y canadiense, con sus ejércitos bien armados, sus ferrocarriles bien financiados y su demás tecnología y capital. La ciencia también estuvo inicialmente del lado de los invasores. Pero después de la Primera Guerra Mundial esa frontera comenzó a sufrir de escasez de tierra abundante y libre. Entonces comenzó lo que yo llamo la ciencia de "pos-frontera", especialmente ecológica en cuanto a contenido, que representaba una actitud muy diferente frente a la conquista del hombre blanco. Científicos como Frederick Clements, John C. Weaver, Paul Sears y Stan Rowe, todos nativos de las Grandes Praderas, establecieron los fundamentos de lo que ahora es una crítica poderosa a la agricultura de frontera. Este artículo resume esa crítica brevemente, pero se enfoca en el trabajo, más reciente, de Wes Jackson, fundador y presidente por largo tiempo del Land Institute. Él ha criticado extensamente el ethos de la frontera debido a su falta de comprensión de la ecología nativa de las llanuras. En su lugar, ofrece una visión de un "policultivo perenne", que usa la naturaleza como modelo para la agricultura en una era de límites. Ese modelo no sólo ha tenido un impacto creciente en el pensamiento estadounidense sino que se ha expandido a otros continentes. ¿Será que este fin del ciclo de la frontera y su revaluación científica darán el giro hacia lo que Jackson llama una "nueva agricultura", basada en el aprendizaje del pasado y que pueda cambiar la forma de cultivar en el mundo?
\end{abstract}

Palabras Clave: Historia Ambiental; Agricultura de Frontera; Wes Jackson; Land Institute.

Recibido: $16 / 12 / 2020$

Aprobado: $18 / 02 / 2020$ 